\title{
Experience of biotechnology method applications in meat processing industry
}

\author{
Maksim M. Danyliv ${ }^{1, *}$, Olga A. Vasilenko ${ }^{2}$, Olga N. Ozherelyeva ${ }^{1}$, and Ekaterina B. Stanislavskaya ${ }^{1}$ \\ ${ }^{1}$ Voronezh state university of engineering technologies, Voronezh 394036, Russia \\ ${ }^{2}$ Voronezh State Agrarian University named after Emperor Peter the Great, Voronezh 394087, Russia
}

\begin{abstract}
Nowadays one of the main regulatory documents governing the future of food production in Russia is the "Food Security Doctrine of the Russian Federation" formulated in order to implement the state economic policy in the field of ensuring food security of the Russian Federation, aimed at reliable provision of the country's population with food products, the development of domestic agricultural and fishery complexes. In the past 40 years, the use of nano- and biotechnologies in the processing of animal and fish raw materials has been widely developed. A large number of scientific studies are aimed at biotechnology method applications in the production of meat products, in particular the use of enzyme proteolytic preparations. The aim of the research presented in this article was to study the dynamics of the hydrolysis of water-, salt- and alkali-soluble fractions of low-grade beef and lamb proteins with Megaterin, an enzyme preparation of animal origin. The fulfilled studies allow more precise approach to the use of enzyme preparations for the processing of basic raw materials by the meat industry.
\end{abstract}

\section{Introduction}

The development of applied scientific research concerning the introduction of innovative technologies, including biotechnology of food products, is a way to improve the quality of food products giving them functional and / or multifunctional properties [1].

The biotechnological methods of processing raw materials in the meat industry are associated with the creation of advanced technologies, in most cases implemented in the form of targeted use of enzyme systems. According to many scientists, the contribution of biotechnology to the provision of sufficient quantities of food and forage products, environmental protection in a certain sense is much more important than the previously known areas of technical development. Implementation of achievements in the field of enzyme production and use is a realistic way to significantly increase the efficiency of the national economy [2].

Global and domestic studies demonstrate the need for the use of enzyme preparations in the meat industry for processing the blood of slaughtered animals, processing feather and fluff, removing hair from skins, as well as obtaining various kinds of hydrolysates. It is also necessary to specify the methods of enzymatic processing of muscle tissue proteins, which will accelerate the ripening and softening of meat [3], and, consequently, its grades. The quantitative proportion of various fractions of muscle tissue proteins, their condition determines not only the technological properties of raw materials and products, but also their biological value. For efficient and appropriate use of enzyme preparations in the processing of low-grade meat raw materials, it is necessary to perform the experiments that deepen the knowledge concerning their effect on the proteins of various fractions of muscle tissue [4-6].

The proteins of meat and meat products are divided into water-soluble proteins (sarcoplasmic), salt-solution soluble proteins (myofibril), and insoluble in water-salt solutions, conventionally called stromal proteins [7]. The water-soluble fraction of the sarcoplasm includes myogen, myoglobin (natural pigment), myoalbumin and globulin X. Saline-soluble (myofibrillar) proteins include myosin, actin, tropomyosin, and the troponin complex [8-11].

The dynamics of enzymatic hydrolysis of water-, salt- and alkali-soluble fractions of low-grade beef and lamb proteins is a typical illustration of the effect of the enzyme preparation on the content of proteins and amino acids in protein fractions, and at the same time on the biological value and functional and technological properties of raw meat.

The aim of this work was to study the dynamics of the hydrolysis of water-, salt- and alkali-soluble fractions of low-grade beef and lamb proteins with Megaterin, an enzyme preparation of animal origin.

\section{Methods and Equipment}

\subsection{Methods}

As the substrates for determining the biochemical characteristics, we used water and salt and alkali soluble 
protein fractions of meat obtained by sequential extraction with distilled water and Weber saline, respectively.

As an enzyme preparation, domestic prototype Megaterin G 10x was used (specification TU 00479942002-94), concentration 50 proteolytic activity units (PS) per 1 gram of protein in the extract which provides for the maximum level of hydrolysis of the tested fractions. This enzyme preparation is recommended for processing low-grade meat raw materials.

The following indicators were measured during enzymic hydrolysis: mass fraction of protein on biuret reaction and amino acids on ninhydrin method; proteolytic activity of the enzyme preparation and mass fraction of free amino acid tyrosine as an indicator of protein fraction destruction and manifestation of specificity on the disruption of the side chains in protein formed by phenolic ring of tyrosine (Folin reaction for tyrosine and cysteine chemical groups).

\subsection{Equipment}

Enzymic hydrolysis was performed using the device UVMT-12-250 under the temperature $40^{\circ} \mathrm{C}, \mathrm{pH}=7.2-7.6$, and constant mixing $(\mathrm{n}=180 \mathrm{rev} / \mathrm{min})$ during 6 hours. Shake flasks of $250 \mathrm{~cm}^{3}$ were filled with $100 \mathrm{~cm}^{3}$ of protein extracts and after reaching the target temperature with enzyme preparation Megaterin G 10x.

The research object was low-grade beef and lamb with an autolysis period of 4-5 days at the temperature of $2-4{ }^{\circ} \mathrm{C}$, got after the industrial processing of cattle under the conditions of meat processing enterprises of the Central Black Earth Region of the Voronezh Region, the Russian Federation.

The amino acid composition of protein fractions was determined by ion exchange chromatography with the automatic amino acid analyzer T 339 MICROTECHNA (Prague, Czech Republic). The hydrolysis of the samples was carried out in $6 \mathrm{~N} \mathrm{HCl}$ with preliminary oxidation with formic acid at the ratio of 1:9. Amino acids were separated with the analytical column filled with Ostion LGFA ion-exchange resin with stepwise elution with three sodium citrate buffers with different $\mathrm{pH}$ values $(3.50 ; 4.25 ; 9.50)$.

\section{Results}

It is well-known that biological value of meat products is determined by their amino acid composition, as well as digestibility and assimilation. Based on this idea, the amino acid composition of water- and salt-soluble fractions of proteins of category 2 beef was determined. The fractions of the whole muscle tissue were isolated using the described method in the form of dry powdered products (at the temperature of $60{ }^{\circ} \mathrm{C}$ to constant weight) (Fig. 1-2) and the total amino acid composition was determined (Table 1).

As it follows from Table 1, water-soluble fraction of category 2 beef proteins is presented (in descending order) by the amino acids as: phenylalanine $>$ glutamic acid $>$ asparagine acid $>$ histidine $>$ leucine. Mass fraction of amino acids of this fraction does not exceed $27.480 \%$, while the share of the indispensable amino acids in their total is $41.69 \%$.

Table 1. Amino acid composition of various fractions of proteins of category 2 beef

\begin{tabular}{|c|c|c|c|c|}
\hline \multirow[t]{3}{*}{ Amino acids } & \multicolumn{4}{|c|}{ Amino acid concentration } \\
\hline & \multicolumn{2}{|c|}{$\begin{array}{l}\text { water-soluble } \\
\text { fraction }\end{array}$} & \multicolumn{2}{|c|}{$\begin{array}{c}\text { Salt-soluble } \\
\text { fraction }\end{array}$} \\
\hline & $\begin{array}{c}\% \text { of } \\
\text { weight }\end{array}$ & $\begin{array}{l}\mathrm{g} / 100 \mathrm{~g} \\
\text { of } \\
\text { protein }\end{array}$ & $\begin{array}{c}\% \text { of } \\
\text { weight }\end{array}$ & $\begin{array}{l}\mathrm{g} / 100 \mathrm{~g} \\
\text { of } \\
\text { protein }\end{array}$ \\
\hline 1. Asparagine acid & 2.32 & 8.44 & 5.99 & 10.28 \\
\hline 2. Threonine & 1.02 & 3.70 & 3.23 & 5.55 \\
\hline 3. Serine & 0.97 & 3.52 & 2.89 & 4.96 \\
\hline 4. Glutamic acid & 3.75 & 13.64 & 8.91 & 15.29 \\
\hline 5. Proline & 1.73 & 6.30 & 4.13 & 7.09 \\
\hline 6. Glycine & 1.26 & 4.59 & 2.57 & 4.41 \\
\hline 7. Alanine & 1.81 & 6.60 & 4.06 & 6.98 \\
\hline 8. Cystine & 0.29 & 1.05 & 0.42 & 0.72 \\
\hline 9. Valine & 1.50 & 5.47 & 4.16 & 7.13 \\
\hline 10. Methionine & 0.37 & 1.35 & 0.54 & 0.93 \\
\hline 11. Isoleucine & 1.11 & 4.05 & 3.06 & 5.25 \\
\hline 12 Leucine & 2.04 & 7.42 & 5.86 & 10.05 \\
\hline 13. Tyrosine & 1.10 & 3.99 & 0.62 & 1.07 \\
\hline 14. Phenylalanine & 4.15 & 15.11 & 2.95 & 5.06 \\
\hline 15. Histidine & 2.22 & 8.10 & 2.33 & 4.00 \\
\hline 16. Lysine & 1.63 & 5.94 & 5.25 & 9.01 \\
\hline 17. Arginine & 1.29 & 4.68 & 3.32 & 5.69 \\
\hline $\begin{array}{l}\text { Total amino acid } \\
\text { content }\end{array}$ & 28.56 & 100.00 & 60.28 & 100.00 \\
\hline $\begin{array}{l}\text { Indispensable } \\
\text { amino acid content, } \\
\%\end{array}$ & & & & \\
\hline
\end{tabular}

Salt-soluble fraction of category 2 beef proteins is marked by higher share of amino acids: total $-58.260 \%$, indispensable $-41.11 \%$. The following amino acids prevail in their composition, \%: glutamic acid (8.736), asparagine acid (5.872), leucine (5.632), lysine (4.862), and proline (4.048).

We should point out the prevailing dispersion of leucine, glutamic and asparagine acids in the both fractions of category 2 beef proteins (water- and saltsoluble ones) which formed ratio 1:2.12.

The percentage of indispensable amino acids in both fractions is very similar $-41.11-41.69 \%$.

Complete idea of the biological value of the tested protein fractions determined by the chemical method consists in comparing their amino acid composition with the ideal amino acid scale (FAO / WHO scale) calculation of amino acid scores, KRAS, utility index, and comparable redundancy index. Table 2 shows the indicators of the biological value of muscle tissue of category 2 beef and its fractions.

The amino acid score of valine, isoleucine, leucine, lysine, and threonine of the water-soluble fraction and whole muscle tissue are close to the reference indicators. The amino acid score of salt-soluble fraction deviates considerably from the standard - 26 compared to $55 \%$. Thus, KRAS values are $12.6 \%$ for muscle tissue, $58.5 \%$ for water-soluble fraction, but the largest deviation is for salt-soluble fraction, that is $73.5 \%$. Thus, muscle tissue 
has the greater biological value, and water soluble fraction is more valuable $(41.5 \%)$ out of the two tested fractions. Similar indicator for the salt-soluble fraction does not exceed $26.6 \%$.

Table 2. Indicators of the biological value of muscle tissue of category 2 beef and its fractions

\begin{tabular}{|c|c|c|c|c|c|c|c|}
\hline \multirow{3}{*}{$\begin{array}{c}\text { Indispensable } \\
\text { amino acid }\end{array}$} & \multicolumn{4}{|c|}{$\begin{array}{l}\text { Concentration, } \\
\mathrm{g} / 100 \mathrm{~g} \text { of protein }\end{array}$} & \multirow{2}{*}{\multicolumn{3}{|c|}{ Biological value, $\%$}} \\
\hline & \multirow[b]{2}{*}{$\begin{array}{c}\text { FAO/ } \\
\text { WHO } \\
\text { standard }\end{array}$} & \multicolumn{3}{|c|}{ Category 2 beef } & & & \\
\hline & & 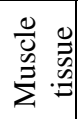 & 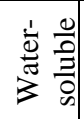 & 咅 $\frac{0}{3}$ & 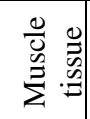 & 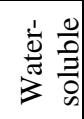 & 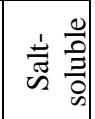 \\
\hline Valine & 5.0 & 5.61 & 5.29 & 6.87 & \multirow{8}{*}{86.98} & \multirow{8}{*}{42.35} & \multirow{8}{*}{27.01} \\
\hline Isoleucine & 4.0 & 4.42 & 3.87 & 5.09 & & & \\
\hline Leucine & 7.0 & 8.12 & 7.12 & 9.69 & & & \\
\hline Lysine & 5.5 & 8.14 & 5.72 & 8.38 & & & \\
\hline $\begin{array}{c}\text { Methionine }+ \\
\text { cystine }\end{array}$ & 3.5 & 4.62 & 2.29 & 1.58 & & & \\
\hline Threonine & 4.0 & 4.12 & 3.48 & 5.32 & & & \\
\hline Tryptophane & 1.0 & 1.11 & - & - & & & \\
\hline $\begin{array}{c}\text { Phenylalanin } \\
\mathrm{e}+\text { tyrosine }\end{array}$ & 6.0 & 8.01 & 18.62 & 5.87 & & & \\
\hline
\end{tabular}

The observed data on the amino acid compositions of various fractions of meat proteins give a clear idea of their potential biological value, the direction of possible changes, and the nature of the final products of enzymatic hydrolysis by proteolytic preparations [12].

The enzyme preparation megaterin (alkaline protease) is intended for use as a biocatalyst. Megaterin is obtained by cultivating the microorganism Bacillus megaterium in a nutrient medium containing fodder yeast, corn flour, calcium chloride, sodium hydroxide. At finishing the fermentation process, the target preparation is isolated, purified and dried, and the waste product - the biomass of cells separated from the native solution, is subjected to factory heat treatment at $(135 \pm 2){ }^{\circ} \mathrm{C}$ for $(60 \pm 1) \mathrm{min}$. (Pilot industrial regulations for the production of the enzyme preparation megaterin. PIR 29-94. Approved 04.10.94. Ferment preparation factory of Vyshny Volochek).

Graphic presentation of the hydrolysis experiments is shown in Fig. 1.

Hydrolysis of water- and salt-soluble fractions of beef and lamb proteins of the second grade occurs most intensively in the first 3-4 hours, then from 3 to 6 hours it slows down and remains at approximately the same level until the end of the experiment.

Thus, protein concentration in water- and salt-soluble fractions of beef reduces from 5.31 and $6.1 \mathrm{mg} / \mathrm{cm}^{3}$ at the beginning to 2.796 and $3.11 \mathrm{mg} / \mathrm{cm}^{3}$ by the end of hydrolysis process; accordingly, protein concentration in water- and salt-soluble fractions of lamb dropped in 6 hours of hydrolysis from 6.1 and $6.6 \mathrm{mg} / \mathrm{cm}^{3}$ to 3.65 and $4.15 \mathrm{mg} / \mathrm{cm}^{3}$, correspondingly. Enzyme preparation megaterin G 10 x more efficiently hydrolyzes the water and salt-soluble fractions of beef proteins by 47.3 and $49.0 \%$, the effect of the preparation for lamb protein fractions by 40.2 and $37.12 \%$ is less pronounced. Equalization of the curves of protein concentrations in solution (Fig. 1), starting from $4 \mathrm{~h}$ until the end of hydrolysis, in all tested fractions may indicate the following possible directions of the enzymatic hydrolysis process: complete inactivation of the enzyme preparation; the effect of the preparation is limited due to its substrate specificity.

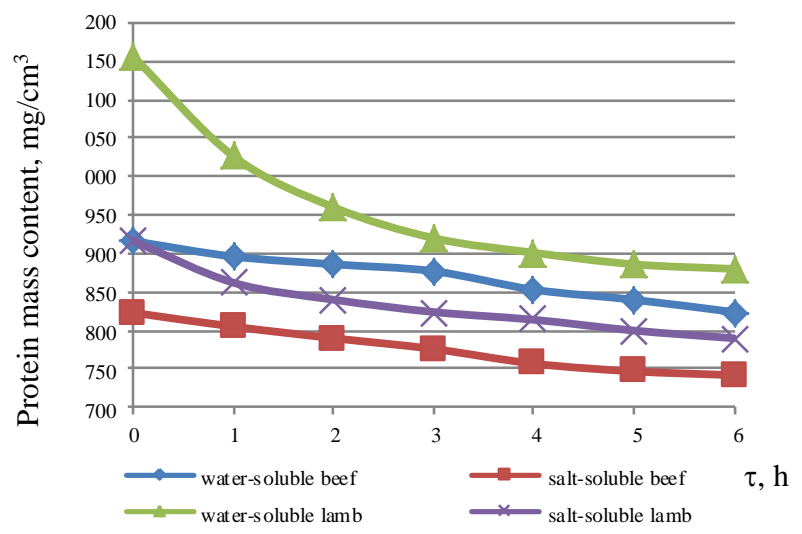

Fig. 1. Dynamics of the process of hydrolysis of water- and salt-soluble fractions of low-grade beef and lamb proteins with the enzyme preparation Megaterin G $10 \mathrm{x}$

To verify the first assumption, we simultaneously studied changes in the activity (PS) of the enzyme preparation Megaterin in all four substrates (Fig. 2).

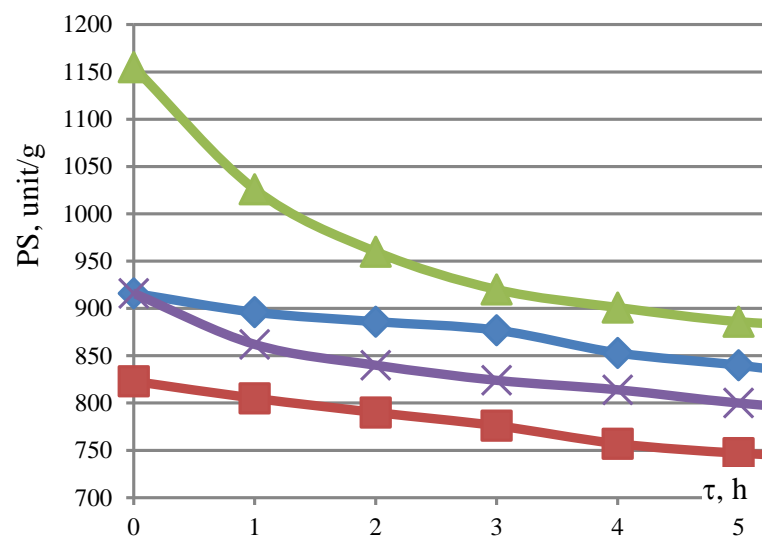

Fig. 2. Dynamics of the activity of the enzyme preparation Megaterin G 10 x during the hydrolysis of water and saltsoluble fractions of low-grade beef and lamb proteins

As it was demonstrated by the experiment results, residual activity (PS) of the enzyme preparation of the tested fractions was as follows, \%: water-soluble beef fraction - 89.96; salt-soluble beef fraction - 90,16; water-soluble lamb fraction - 76.2; salt-soluble lamb fraction -86.24 . Proteolytic activity remained at the comparatively high level between 76.2 and $90.16 \%$, which means the complete inactivation of the preparation never happened.

The shape of all the curves of changes in the activity of the preparation in the last hours of hydrolysis (from 4 to 6 hours) emphasizes that the inactivation of the preparation occurred mainly not due to the influence of changes in the environment from $\mathrm{pH}$ and temperature in this case, there would be further continuous decrease in the activity curves, as in the first 3 hours of hydrolysis. Apparently, inactivation of the enzyme takes 
place with the end hydrolysis products - amino acids, peptides (due to the fact that the resulting peptides and amino acids are neutral or increase the proteolytic activity of the enzyme preparation). The latter assumption is also supported by the results of the dynamics of protein hydrolysis to low molecular weight products during the first 3 hours (Fig. 1-2). Starting from the 4th hour, protein hydrolysis ceases and, accordingly, further inactivation of the enzyme preparation is suspended (Fig. 2).

Graphic data of the results of the study of the dynamics of hydrolysis of alkali-soluble fractions is presented in Figure 3.

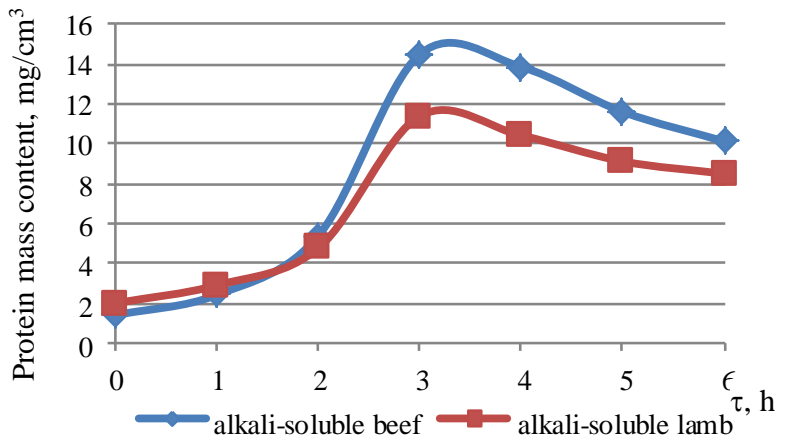

Fig. 3. Dynamics of the hydrolysis process of the alkali-soluble fraction of low-grade beef and lamb proteins with the enzyme preparation Megaterin G $10 \mathrm{x}$

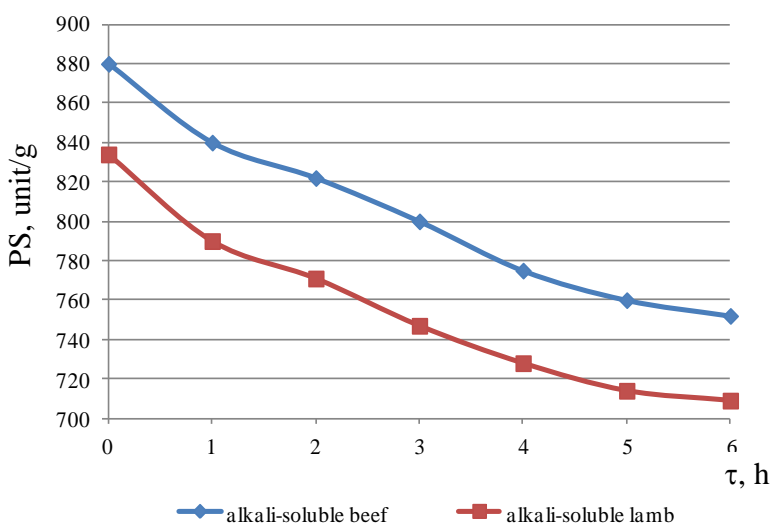

Fig. 4. Activity dynamics of the enzyme preparation Megaterin $\mathrm{G} 10 \mathrm{x}$ during hydrolysis of the alkali-soluble fraction of lowgrade beef and lamb proteins

It follows that at the initial moment of hydrolysis, the bulk of the protein is in the undissolved state, only $1.4 \mathrm{mg} / \mathrm{cm}^{3}$ is in the dissolved state for the alkalinesoluble beef fraction and $2.0 \mathrm{mg} / \mathrm{cm}^{3}$ for the alkalinesoluble lamb fraction. Then there is intensive transition of the insoluble protein to the dissolved one and by the end of 3 hours it amounts to $14.5 \mathrm{mg} / \mathrm{cm}^{3}$ for the alkalisoluble fraction of beef and $11.4 \mathrm{mg} / \mathrm{cm}^{3}$ for the alkalisoluble fraction of lamb. After 3 hours, there is intensive hydrolysis of the dissolved protein to peptides and amino acids, and by the end of the hydrolysis, the protein content is $8.5 \mathrm{mg} / \mathrm{cm}^{3}$ for lamb and $10.19 \mathrm{mg} / \mathrm{cm}^{3}$ for beef i.e. the protein content in the last 4-6 hours decreased by $29.7 \%$ for beef and $25.4 \%$ for lamb. The data in Figure 4 show similar dependence of the residual activity (PS) of the enzyme preparation for both water- and salt-soluble fractions of the protein and is, \%: alkalisoluble beef fraction - 85.45; alkali soluble lamb fraction - 85.01. In enzymatic hydrolysis of protein, peptides and amino acids are sequentially produced. The ninhydrin method allows determining both polypeptides with free $\alpha-\mathrm{NH}_{2}$-groups and $\varepsilon-\mathrm{NH}_{2}$-groups of lysine amino acid residues.

Therefore, when detecting these products in the dynamics of accumulation, we can assume the two-phase nature of the curve, where the first section of the curve corresponds to gradual growth of polypeptide content while protein hydrolysis, while the second does to sharp increase in amino acid content as a result of further enzymatic hydrolysis of the polypeptides.

\section{Discussion}

Thus, water-, salt- and alkali-soluble fractions of lowgrade beef proteins are hydrolyzed by the proteolytic enzyme preparation megaterin by $47.3,49.0$ and $29.7 \%$, the same low-grade lamb fractions - by $40.2,37.12$ and $25.4 \%$. Protein hydrolysis takes place in the first 3 hours, with the formation of significant amounts of peptide fractions, which can partially inactivate the enzyme preparation by $5.7-11.5 \%$ of activity. The enzyme preparation megaterin does not have specificity for the hydrolysis of peptide bonds involving tyrosine.

\section{Conclusion}

The performed studies allow more focused approach to the use of enzyme preparations for the processing of basic raw materials in the meat industry. Thus, by directedly influencing protein fractions of the composition of meat raw materials, it is possible to obtain a variety of technological and nutritional forms with predetermined functional and technological properties, which will expand the range of products and give them preventive properties. The total of results makes it possible to outline the ways of processing plant proteins using biotechnological methods in order to obtain easily digestible forms of proteins.

\section{References}

1. T. Tantamacharik, A. Carne, D. Agyei, E. Birch, A. Bekhit, Use of Plant Proteolytic Enzymes for Meat Processing (2018) DOI: 10.1007/978-3-319-971322_3

2. D. Nowak, Enzymes in Tenderization of Meat - The System of Calpains and Other Systems - a Review, Polish J. of Food and Nutrit. Sci., 61 (2011) DOI: 10.2478/v10222-011-0025-5

3. M.S. Arshad, J.-H. Kwon, M.A. Imran, A. Aslam, I. Nawaz, Plant and bacterial proteases: A key towards improving meat tenderization, a mini review, Cogent Food And Agricult., 2, 1-10 (2016)

4. S. S. Moon, Effect of Proteolytic Enzymes and Ginger Extract on Tenderization of M. pectoralis profundus from Holstein Steer, Korean J. for food 
sci. of animal res., 38(1), 143-151 (2018) DOI: 10.5851/kosfa.2018.38.1.143

5. A.Y. Marques, M.R. Maróstica, G.M. Pastore, Some nutritional, technological and environmental advances in the use of enzymes in meat products, Enzyme res., 480923 (2010) DOI: $10.4061 / 2010 / 480923$

6. M. Doneva, I. Nacheva, S. Dyankova, P. Metodieva, D. Miteva, Application of plant proteolytic enzymes for tenderization of rabbit meat, Biotechnol. in Animal Husbandry, 34 (2018) DOI: 10.2298/BAH1802229D

7. J. Whitaker, The Proteolytic Enzymes (2018) DOI: 10.1201/9780203742136-19

8. S. Maqsood et al., Degradation of myofibrillar, sarcoplasmic and connective tissue proteins by plant proteolytic enzymes and their impact on camel meat tenderness, J. of food sci. and technol., 55(9),
3427-3438 (2018) DOI: 10.1007/s13197-018-32516

9. Longteng Zhang, Yuqi Zhang, Shiliang Jia, Yan Li, Qian Li, Kaifeng Li, Hui Hong 洪惠, Yongkang Luo, Stunning stress-induced textural softening in silver carp (Hypophthalmichthys molitrix) fillets and underlying mechanisms, Food Chem., 295 (2019) DOI: 10.1016/j.foodchem.2019.05.148.

10. G. Salvesen, H. Nagase, Inhibition of proteolytic enzymes. Proteolytic enzymes: A practical approach (1989)

11. A. Ouali, Proteolytic enzymes and tenderness of meat, Viandes et Produits Carnes, 16, 81-88 (1995)

12. L.V. Antipova, Ch.Yu. Shamhanov, M.M. Danyliv, Enzymic hydrolysis water-and salt-soluble fraction of proteins of category 2 lamb, News of univer. Food Technol., 4 (2004) 